\title{
Chemotactic Activity of Site-Specific Multivalent Conjugates of Stromal Cell-Derived Factor $1 \alpha$ on Branched Nanoparticles
}

\author{
Yu-Fang Hsieh, Fang Huang, Shyam Patel, Song $\mathrm{Li}^{*}$ \\ Department of Bioengineering and Medicine, University of California, Los Angeles (UCLA), Los Angeles, CA, USA \\ Email: *songli@ucla.edu
}

How to cite this paper: Hsieh, Y.-F., Huang, F., Patel, S. and Li, S. (2018) Chemotactic Activity of Site-Specific Multivalent Conjugates of Stromal Cell-Derived Factor $1 \alpha$ on Branched Nanoparticles. Journal of Biomaterials and Nanobiotechnology, 9, 51-63. https://doi.org/10.4236/jbnb.2018.91005

Received: August 28, 2017

Accepted: January 8, 2018

Published: January 11, 2018

Copyright (c) 2018 by authors and Scientific Research Publishing Inc. This work is licensed under the Creative Commons Attribution International License (CC BY 4.0).

http://creativecommons.org/licenses/by/4.0/

\begin{abstract}
Stromal cell-derived factor $1 \alpha(\operatorname{SDF} 1 \alpha)$ is a potent chemokine for the recruitment of stem cells. A challenge is to maintain its activity and control its release. In this study, we engineered a recombinant cysteine-SDF1 $\alpha$ (cysSDF1 $\alpha$ ) protein, and performed multivalent conjugation of cysSDF1 through the maleimide functional group to two forms of branched nanoparticles: multi-arm poly (ethylene glycol) (MA-PEG) and hyaluronic acid (HA). We characterized the chemotactic activity of the conjugates, and determined how the molecular weight (MW) of MA-PEG and HA affected the chemotactic activity. CysSDF1 $\alpha$ had similar efficiency to wild-type SDF1 $\alpha$ in cell recruitment. Multivalent conjugation of cysSDF1 $\alpha$ to low MW MA-PEG $(\sim 18 \mathrm{~nm})$ did not significantly affect the chemotactic activity, while the conjugation of cysSDF1 $\alpha$ to high MW MA-PEG $(\sim 72 \mathrm{~nm})$ lowered the efficiency, possibly due to the larger spacing between conjugated SDF1 $\alpha$ molecules. HA has a linear backbone and a high density of multivalent binding sites; however, the chemotactic activity of HA-linked cys-SDF1 $\alpha$ was much lower, which further decreased with the increase of HA MW from $200 \mathrm{kDa}(\sim 0.78 \mu \mathrm{m})$ to $700 \mathrm{kDa}(\sim 2.7 \mu \mathrm{m})$. Digestion of HA into smaller fragments using hyaluronidase partially recovered the chemotactic activity of cysSDF1 $\alpha$, suggesting that high MW HA might exert steric hindrance for SDF1 $a$ binding to its receptors on cell surface and that HA could be used as a depot for SDF1 $\alpha$ storage and release. These results demonstrate that multivalent conjugates of SDF $1 \alpha$ to nanoparticles may be used to engineer SDF $1 \alpha$ delivery for cell recruitment and tissue regeneration.
\end{abstract}

\section{Keywords}

SDF1 $\alpha$ Delivery, Cell Recruitment, Site-Specific Protein Ligation, Multivalent Protein Conjugates 


\section{Introduction}

Stromal cell-derived factor $1 \alpha(\operatorname{SDF} 1 \alpha)$ is a chemokine released by bone marrow stromal cells for homing hematopoietic stem cells (HSCs) via a receptor-ligand CXCR4-CXCL12 interaction [1] [2] [3]. In addition, SDF1 $\alpha$ can be released upon tissue injury and recruit bone marrow cells, stem cells and progenitor cells for tissue regeneration [4]-[11]. However, the transient release of SDF1 $\alpha$ by native tissues may not be sufficient to induce sustained responses for tissue repair. Therefore, drug delivery approaches have been developed to release SDF1 $\alpha$ to promote tissue regeneration [12] following myocardial infarction [13] [14], muscle [15], liver [16], and neural regeneration [17]. Several methods have been developed to immobilize SDF $1 \alpha$ onto delivery vehicles, mainly relying on heparin-mediated binding, in which the heparin covalently links to the vehicles via an $\mathrm{NH}_{2}-\mathrm{PEG}-\mathrm{NH}_{2}$ linker or hydrogel linker, and SDF1 $\alpha$ is then immobilized to the conjugated heparin through its heparin-binding domain [18]-[24]. It has been shown that clustering of vascular endothelial growth factors [25], fibroblast growth factor-2 [26], or epidermal growth factors synergistically increases the activity by inducing receptor dimerization [27]. However, it is not clear whether multivalent conjugation of SDF1 $\alpha$ onto nanoparticles affects its activity and potency.

Non-specific conjugation of proteins can occur at every amine group and carboxyl group, including lysine, $\mathrm{N}$ terminus, glutamic acid, and aspartic acid, and thus increases heterogeneity of molecular orientation and bioactivity. To preserve protein bioactivity and yield during ligation, several site-specific methods have been previously created to ligate proteins such as intein-mediated ligation, basic expressed protein ligation, sortase-tag expressed protein ligation, Staudinger ligation and ligation via the thiol group and maleimides [28]-[35]. To engineer SDF1 $\alpha$, we encoded an extra cysteine residue as a linking site at the $\mathrm{C}$ terminus since the $\mathrm{N}$ terminus of $\mathrm{SDF} 1 \alpha$ is closed to its binding domain to its receptor. This engineered cysSDF1 $\alpha$ was linked to the maleimide functional group in multi-arm poly (ethylene glycol) (MA-PEG) or the backbone of hyaluronic acid (HA). We then investigated the effects of multivalent conjugations on the chemotactic activity of SDF $1 \alpha$.

\section{Materials and Methods}

\subsection{Prepare (WT)-SDF1 $\alpha$ and Cysteine (cys)SDF1 $\alpha$}

\subsubsection{Cloning of Wild-Type (WT)-SDF1 $\alpha$ and Cysteine (cys)SDF1 $\alpha$}

DNA plasmids for WT-SDF $1 \alpha$ and cysSDF $1 \alpha$ were designed and constructed. To express WT-SDF1 $\alpha$ and cysSDF1 $\alpha$, Rosetta 2(DE3)pLysS competent cells were transformed with 2AT- WT-SDF1 $\alpha$ and 2AT-cysSDF1 $\alpha$ plasmids, respectively, and subsequently cultured on agar plates containing carbenicillin $(100 \mu \mathrm{g} / \mathrm{ml})$. A single colony was picked and incubated overnight in $25 \mathrm{~mL}$ of $2 \mathrm{YT}$ media with carbenicillin $(100 \mu \mathrm{g} / \mathrm{ml})$ on a shaker at $37^{\circ} \mathrm{C}$. One liter of $2 \mathrm{YT}$ media with carbenicillin $(100 \mu \mathrm{g} / \mathrm{ml})$ was inoculated with $10 \mathrm{~mL}$ of the overnight starter culture and incubated with shaking at $37^{\circ} \mathrm{C}$. When $\mathrm{OD}_{600 \mathrm{~mm}}$ of the culture reached 0.6 , 
IPTG was added to achieve a final concentration of $1 \mathrm{mM}$ to induce protein expression. Induced cells were allowed to grow for 4 hours and subsequently were harvested by centrifuging at $4000 \mathrm{rpm}$ for 15 minutes. The cell pellets were re-suspended in $20 \mathrm{~mL}$ of PBS with 10\% glycerol and homogenized. The cell lysate was centrifuged at $15,000 \mathrm{rpm}$ for 30 minutes at $4^{\circ} \mathrm{C}$. WT-SDF $1 \alpha$ and cysSDF $1 \alpha$ were found in the inclusion bodies.

\subsubsection{Isolation and Refolding of WT-SDF $1 \alpha$ and cysSDF1 $\alpha$}

WT-SDF $1 \alpha$ and cysSDF $1 \alpha$ were extracted and isolated following previously published protocol [3]. In short, inclusion bodies were washed 3 times with buffer A (100 mM Tris-HCl, 5 mM EDTA, 5 mM dithiothreitol, $2 \mathrm{M}$ urea, 2\% Triton X-100, $\mathrm{pH}$ 8.0) and once with buffer B (100 mM Tris- $\mathrm{HCl}, 5 \mathrm{mM}$ EDTA, $5 \mathrm{mM}$ dithiothreitol, $\mathrm{pH}$ 8.0). During each wash, the supernatant was discarded, and inclusion bodies were re-suspended in the buffer thoroughly and sonicated for $5 \mathrm{mi}$ nutes. Re-suspended samples were subsequently centrifuged at $13,000 \mathrm{rpm}$ at $4^{\circ} \mathrm{C}$ for 20 minutes. After the last wash with buffer B, inclusion body pellet was solubilized in $6 \mathrm{M}$ guanidine- $\mathrm{HCl}(5 \mathrm{~mL}$ guanidine- $\mathrm{HCl}$ per $1 \mathrm{~L}$ bacterial culture), and diluted 1:100 into refolding buffer (100 mM Tris- $\mathrm{HCl}, 5 \mathrm{mM}$ EDTA, $0.2 \mathrm{mM}$ oxidized glutathione, $1 \mathrm{mM}$ reduced glutathione, $\mathrm{pH}$ 8.0) and stirred at $4^{\circ} \mathrm{C}$ overnight.

\subsubsection{Purification of WT-SDF1 $\alpha$ and cysSDF1 $\alpha$}

Two different molecular weight cut-off-(MWCO) sized protein concentrators were used to desalt and purify WT-SDF $1 \alpha$ and cysSDF $1 \alpha$. Refolded WT and cysSDF $1 \alpha$ were filtered through a $0.22 \mu \mathrm{m}$ filter system to remove cell debris and other large insoluble compounds. Protein samples were subsequently concentrated with $5 \mathrm{~K}$ MWCO UF centrifugal concentrators (Corning). This concentration step simultaneously removed contaminants that were smaller than $5 \mathrm{~K}$ MWCO in average size. Concentrated protein samples were diluted in storage buffer (10 mM HEPES, 150 $\mathrm{mM} \mathrm{NaCl}, \mathrm{pH}$ 7.9) and concentrated again, using the same $5 \mathrm{~K}$ MWCO concentrators. This dilution followed by a concentration step was repeated a few times using storage buffer to remove refolding buffer at the greatest extent. Lastly, the protein samples were filtered through $30 \mathrm{~K}$ MWCO centrifugal concentrators (EMD Millipore) to remove contaminant proteins bigger than $30 \mathrm{~K} \mathrm{MWCO}$ in average size. SDS-PAGE was performed on final purified protein followed by Simply Blue staining (Thermo Fisher) and Western blotting procedures to determine the protein purity. The commercially available SDF1 $\alpha$ ELISA kit (R\&D Systems) was used to quantify the SDF1 $\alpha$ concentration.

\subsection{Prepare MA- and HA-SDF1 $\alpha$}

Multivalent SDF1 $\alpha$ (HA and MA) conjugation and buffer exchange EMCH-HA ligation. Before conjugating cysSDF1 $\alpha$ to $\mathrm{HA}$, the HA was modified with a maleimide linker, following the method published by the Healy group. Two sizes of HA sodium salt were purchased from Lifecore Biomedical with molecular weights 
of around $200 \mathrm{kDa}$ and $700 \mathrm{kDa}$ (more precisely, weights in the ranges $151-300$ $\mathrm{kDa}$ and $500-749 \mathrm{kDa}$ ). A quantity of $12 \mathrm{mg}$ of $\mathrm{HA}$ was weighed and dissolved in $3 \mathrm{~mL}$ of a $0.1 \mathrm{M} \mathrm{pH} 6.5 \mathrm{MES}$ buffer, by slowly rotating the solution at $4^{\circ} \mathrm{C}$ overnight. Then, $4.8 \mathrm{mg} \mathrm{N}-\mathcal{E}$-maleimidocaproic acid hydrazide linker (EMCH, ThermoFischer, \#22106) was mixed with $40 \mathrm{mg}$ 1-ethyl-3-(3-dimethy-laminopropyl) carbodiimide (EDC) (Sigma Aldrich, \#03450) in a 1mL tube. Slightly more than 4.8 mg 1-hydroxybenzotriazole hydrate (HOBt, Sigma Aldrich, \#54804) was weighed in a separate tube, which then was also rotated. The two tubes were mixed together and rotated for 8 seconds, and then this solution was added into the HA solution. To thoroughly mix all reagents, the result was pipetted up and down, and then the solution was rotated for 4 hours at $4^{\circ} \mathrm{C}$. Next, we activated a 100 $\mathrm{kDa}$ cut-off dialysis tube (Float-A-Lyzer) by incubating the dialysis tube in $10 \%$ ethanol for 10 minutes, and then soaking it in di-water for 15 minutes. We added a total of $4 \mathrm{~mL}$ of the sample into the dialysis tube and dialyzed it against 400 mL 1X PBS with $10 \%$ glycerol overnight. We changed to a fresh buffer and performed dialysis for another 4 hours the next day. The utilized ratio of sample volume to dialysis volume was 1:100. The samples were then aliquoted and slowly frozen to $-20^{\circ} \mathrm{C}$. Below, we denote the sample with $200 \mathrm{HA}$ backbone as $200 \mathrm{HABB}$, and the sample with $700 \mathrm{HA}$ backbone as $700 \mathrm{HABB}$.

cysSDF $1 \alpha$-HA ligation. We took $5 \mu \mathrm{L}$ of $200 \mathrm{HABB}$ or $5 \mu \mathrm{L}$ of $700 \mathrm{HABB}$ to mix with $422 \mu \mathrm{L}$ cysSDF1 $\alpha$. The $\mathrm{pH}$ value was measured by adding a drop on the $\mathrm{pH}$ indicator paper, and then the $\mathrm{pH}$ value was adjusted to $\mathrm{pH} 6.5$ by adding 0.1 $\mathrm{M} \mathrm{HCl}$ drop by drop. The solution was rotated at $4^{\circ} \mathrm{C}$ overnight. A $100 \mathrm{kDa}$ cut-off dialysis tube was activated by the protocol described above. A total volume of $427 \mu \mathrm{L}$ of the sample was added into the dialysis tube, and dialyzed against a $40-\mathrm{mL}(\mathrm{pH} 7) \mathrm{PBS}$ buffer at $4^{\circ} \mathrm{C}$ overnight for the exchanged buffer. $\mathrm{A}$ pipette was used to measure the sample volume. We detected the amount of cysSDF1 $\alpha$ in the dialyzed solution via ELISA, which indicates the unbound cysSDF $1 \alpha$ monomer. Subtracting the amount of unbound cysSDF1 $\alpha$ from the total amount of cysSDF $1 \alpha$ used quantifies the cysSDF $1 \alpha$ that ligated to the HA. These cysSDF $1 \alpha$ ligated to the HA backbone are $200 \mathrm{HA}$ and $700 \mathrm{HA}$.

cysSDF1 $\alpha$-MA-PEG ligation. Two sizes of (4-arm) multi-arm-PEG-maleimides (MA-PEG backbone) were purchased from Sunbright with molecular weights of 10 $\mathrm{kDa}$ and $40 \mathrm{kDa}$. We serial diluted $10 \mathrm{kDa}$ and $40 \mathrm{kDa}$ multi-arm-PEG-maleimide to $1 \mu \mathrm{g} / \mu \mathrm{L}$. The mole ratio of 1:4 was used for backbone to cysSDF1 $\alpha$ while preparing the reaction: specifically, we added $0.1 \mu \mathrm{L}$ of $10 \mathrm{kDa}$ backbone or $40 \mathrm{kDa}$ backbone to $320 \mu \mathrm{L}$ or $80 \mu \mathrm{L}$ of cysSDF $1 \alpha$, respectively. As above, the $\mathrm{pH}$ value was adjusted to a level of $\mathrm{pH} 6.5$. We rotated the solution at $4^{\circ} \mathrm{C}$ overnight. The solution was dialyzed with a $20 \mathrm{kDa}$ cut-off dialysis tube (Float-A-Lyzer) by 40 $\mathrm{mL} \mathrm{pH} 7 \mathrm{PBS}$ buffer at $4^{\circ} \mathrm{C}$ overnight for the exchanged buffer. At this point, the same methods as we used for the HA above to purify and quantify the sample were used here for MA-PEG. These cysSDF1 $\alpha$ ligated to the MA backbone are 10MA-PEG and 40MA-PEG. 


\subsection{Characterize and Detect Potency}

\subsubsection{Chemotaxis Assay}

The chemotaxis assay was performed by using the Boyden chamber system in 96-well-transwell plates (Corning HTS-Transwell-96-well Plate, \#3389) with 5- $\mu \mathrm{m}$ pore size polycarbonate membranes. Jurkat T-lymphocytic cells (Scientific Facilities, UC Berkeley) were maintained in RPMI media with $10 \%$ fetal bovine serum (FBS). For the chemotaxis assay, Jurkat cells were trypsinized and re-suspended in RPMI media with $1 \% \mathrm{FBS}$, and $100 \mu \mathrm{L}$ of cell suspension $(3,000,000-5,000,000$ cells $/ \mathrm{mL}$ ) was added to each well. SDF1 $\alpha$ variants and conjugates were added to the lower chamber at the desirable concentration, and incubated at $37^{\circ} \mathrm{C}$ for 4 hours. Then the cells suspended in the bottom wells were counted with a hemocytometer.

\subsubsection{Release of Conjugated SDF1 $\alpha$ from HA by Hyaluronidase} $100 \mathrm{ng} / \mathrm{mL}$ of HA complexes and $4 \mathrm{mg} / \mathrm{mL}$ of hyaluronidase (Sigma Aldrich, \#H3506) was dissolved in RPMI media. The solution was incubated at $37^{\circ} \mathrm{C}$ for 1 hour or overnight digestion. After cooling to room temperature, the solution was used for chemotaxis assay.

\subsubsection{Reduced SDS-PAGE Gel}

The samples of all SDF1 $\alpha$ constructs were lyophilized into powder and then reconstituted in $15 \mu \mathrm{L}$ di-water. The $15 \mu \mathrm{L}$ sample was thoroughly mixed with $1 \mu \mathrm{L}$ $\beta$-mercaptoethanol and $4 \mu \mathrm{L}$ sample buffer, and then heated for 5 minutes at $85^{\circ} \mathrm{C}$. The gradient SDS-PAGE gel (Bio-Rad) was used for electrophoresis to separate conjugates. The sample mixture and ladder dye were loaded in the well respectively. The gel was run at $100 \mathrm{~V}$ for 1.5 hours, then stained with a $1 \mathrm{X}$ Coomassie blue staining solution for 3 hours, and washed with di-water overnight.

\section{Results and Discussion}

\subsection{Non-Specific-Linked SDF1 $\alpha$ Does Not Retain Chemotactic Activity}

First, we determined whether clustering of SDF1 $\alpha$ via non-specific covalent crosslinking retains its chemotactic activity. SDF $1 \alpha$ molecules were non-specifically crosslinked using the EDC-NHS coupling method. The EDC-NHS coupling reagent randomly links any carboxyl group to any amine group of the proteins resulting in protein clustering. In principle, linking SDF1 $\alpha$ could increase the bioactivity, but on the other hand, clusters have a high probability of hiding the cell-sensing domains thus leading to lower chemotaxis bioactivity. As shown in Figure 1(a), $10 \mathrm{ng} / \mathrm{mL}$ EDC-crosslinked control SDF1 $\alpha$ (cSDF1 $\alpha$ purchased from Peprotech \#300-28A) had retained minimal dose-dependent chemotactic activity similar to that of FBS, both of which induced significantly lower cell migration than monomeric $\operatorname{cSDF} 1 \alpha$. This result suggested that the site-specific-linking, rather than random linking, might have more potential to retain the activity of the receptor-binding domain after ligation. 


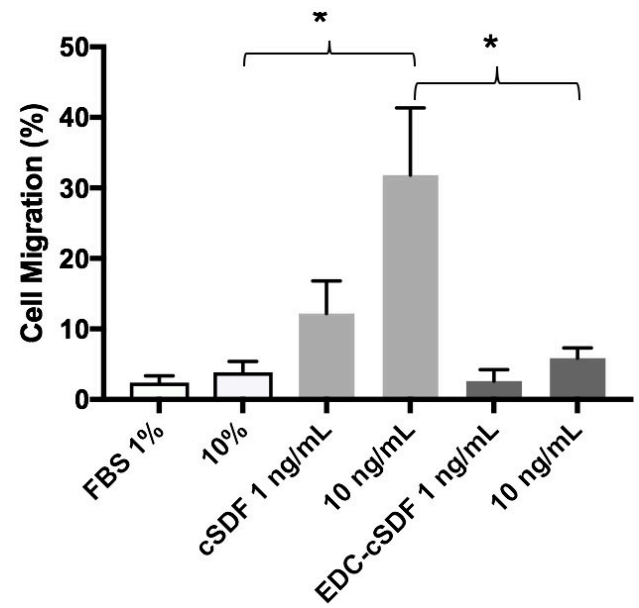

(a)

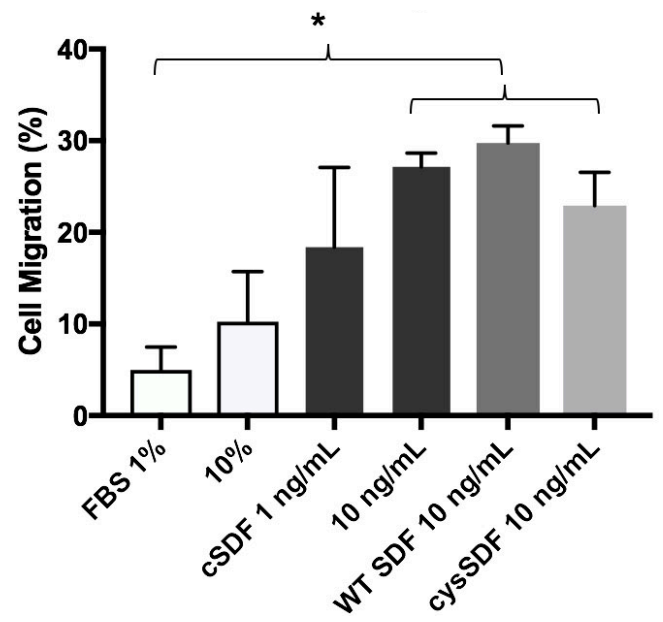

(c)

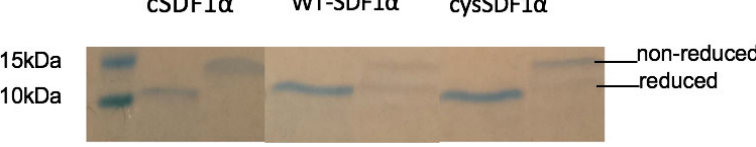

(b)

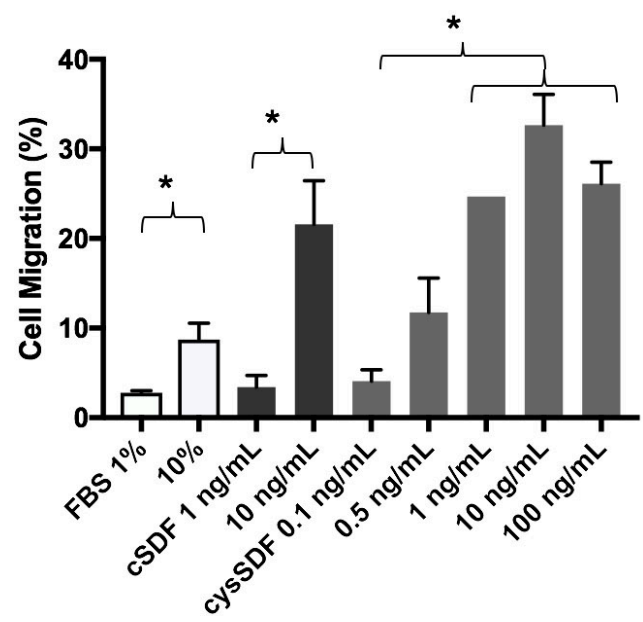

(d)

Figure 1. Effects of randomly conjugated SDF1 $\alpha$ and the characterization of cysSDF1 $\alpha$. (a) Chemotactic bioactivity of randomly linked control SDF1 $\alpha(\operatorname{cSDF} 1 \alpha)$; (b) SDS-PAGE analysis of cSDF1 $\alpha$, WT-SDF1 $\alpha$ and cysSDF1 $\alpha$; (c) Chemotactic bioactivity of $\mathrm{cSDF} 1 \alpha$, WT-SDF $1 \alpha$ and cysSDF $1 \alpha$; (d) Dose titration of cysSDF1 $\alpha$ ranging from 0.1 $\mathrm{ng} / \mathrm{mL}-100 \mathrm{ng} / \mathrm{mL}$. Note: ${ }^{\star}$ indicates a pair has a statistically significant difference $(\mathrm{p}$-value $<0.05)$.

\subsection{Verification of Chemotactic Activity of cysSDF1 $\alpha$}

To enable site-specific-ligation of SDF $1 \alpha$ we added a cysteine residue at the $\mathrm{N}$-terminus of SDF $1 \alpha$, expressed cysSDF $1 \alpha$ proteins in $E$. coli culture, and then purified and re-folded the recombinant protein. Cys-SDF expression and purification were verified via SDS-PAGE. In Figure 1(b), the SDS-PAGE gel showed that both reduced and non-reduced forms of SDF1 $\alpha$ could be purified. To verify that cysSDF1 $\alpha$ folded into the active conformation and retained bioactivity, we tested its chemotactic bioactivity. The results showed that both WT-SDF $1 \alpha$ and cysSDF1 $\alpha$ had similar bioactivity to cSDF1 $\alpha$ at $10 \mathrm{ng} / \mathrm{ml}$ (Figure 1(c)). Dose-titration experiments showed that cysSDF $1 \alpha$ activity exhibited dose dependent increase in the range $0.1-10 \mathrm{ng} / \mathrm{mL}$ and that cysSDF $1 \alpha$ was significantly more potent than cSDF $1 \alpha$ at $1 \mathrm{ng} / \mathrm{ml}$ concentration (Figure $1(\mathrm{~d})$ ). However, cysSDF $1 \alpha 100 \mathrm{ng} / \mathrm{mL}$ did not show further increase of chemotactic activity, which might be attributed 
to the passive dimerization of cysSDF1 $\alpha$ through cysteine at high concentration or the saturation of cysSDF1 $\alpha$-receptor interactions.

\subsection{Chemotactic Study of Multivalent SDF1 $\alpha$ Conjugated to MA-PEG}

We generated multivalent SDF1 $\alpha$ by ligating cysSDF $1 \alpha$ molecules to $10 \mathrm{kDa}$ and $40 \mathrm{kDa}$ maleimide-modified, star-shaped 4-arm PEG via Michael addition reaction (Figure 2(a)). The sizes of the individual arms were around $18 \mathrm{~nm}$ and $72 \mathrm{~nm}$ for 10MA-PEG and 40MA-PEG molecule, respectively (Figure 2(b)).

To determine the efficiency of ligation, 10MA-PEG were concentrated 50-fold by using a lyophilizer after buffer exchanging in a dialysis tube, and then ran in the reduced SDS-PAGE gel. In Figure 3(a), the 10MA-PEG shows 5 different bands around $10-50 \mathrm{kDa}$, corresponding to cysSDF1 $\alpha$ monomer, and 1-, 2-, 3-, and 4-cysSDF1 $\alpha$-linked PEG.

Each band was shifted by roughly $8 \mathrm{kDa}$ (the molecular weight of one SDF1 $\alpha$ molecule). This small difference between these bands made it difficult to separate by size exclusion columns; therefore, we investigated whether this conjugation affected the chemotactic activity by using the heterogeneous mixture of multivalent SDF1 $\alpha$. In this case, the role of the PEG backbone served as an $\operatorname{SDF} 1 \alpha$ carrier to 1 ) to help maintain the bioactivity of $\operatorname{SDF} 1 \alpha$, and 2) to bring

(a)

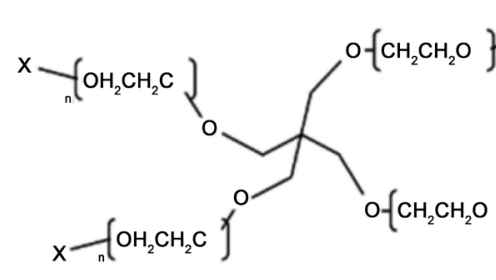

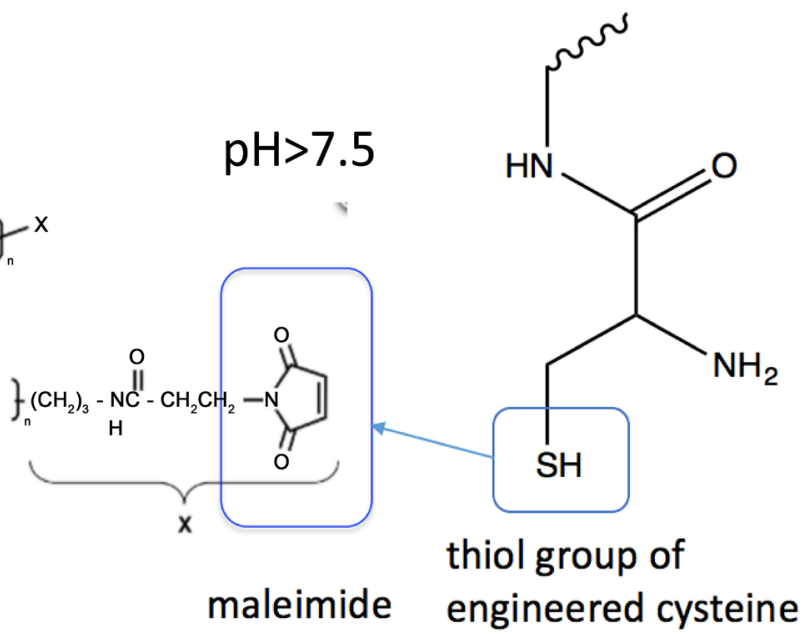

(b)

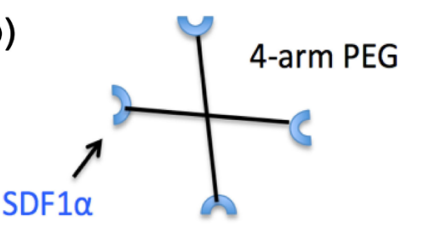

Ethylene glycol (PEG) Mw=62 g/mol $~ 0.45 \mathrm{~nm}$ $10 \mathrm{kDa} \mathrm{MA}$, each arm 18nm 40KDa MA, each arm $\sim 72 \mathrm{~nm}$

\section{Star-shape SDF1 $\alpha$ multivalent}

Figure 2. The structure and chemical reaction of MA SDF1 $\alpha$. (a) The Michael addition reaction between maleimide of 4-arm PEG and thiol group cysSDF1 $\alpha$. This is an addition elimination reaction, working at $\mathrm{pH}>7.5$. Thiol group serves as a medium high nucleophile attacking maleimide, after protonation of malemide, the base $\left(\mathrm{OH}^{-}\right)$group deprotonation of maleimide. At $\mathrm{pH}<7$, the reaction causes failure of deprotonation; (b) The topology and size of MA SDF1 $\alpha$. 


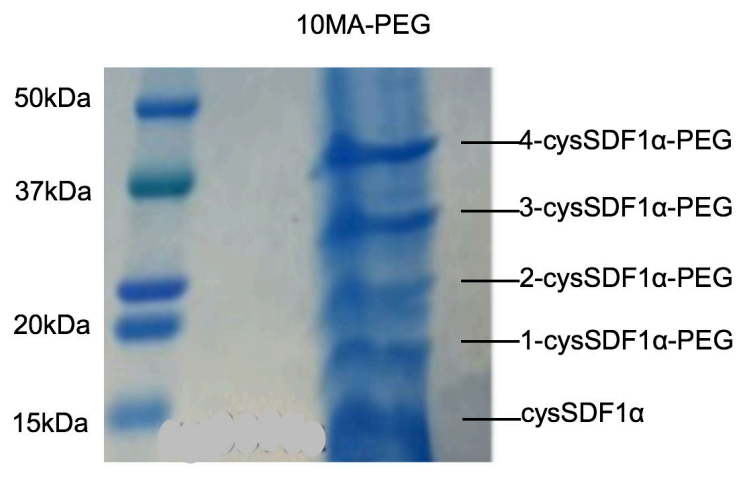

(a)

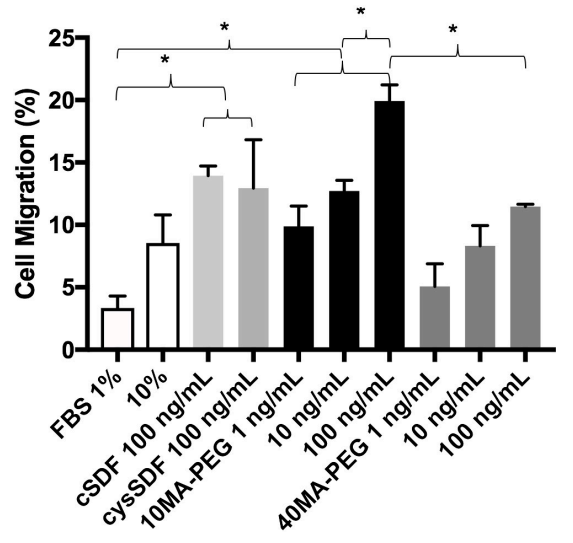

(b)

Figure 3. SDS-PAGE gel and chemotactic bioactivity of MA-PEG. (a) SDS-PAGE gel of 10MA-PEG. In the gel, 10MA-PEG shows five different bands around 10-50 kDa, corresponding to cysSDF1 $\alpha$ monomer, 1, 2, 3, and 4-cysSDF1 $\alpha$-linked PEG, respectively; (b) Chemotactic bioactivity of 10MA-PEG and 40MA-PEG. Note: ${ }^{*}$ indicates a pair has a statistically significant difference ( $\mathrm{p}$-value $<0.05$ ).

SDF1 $\alpha$ molecules together through multivalent conjugation.

The bioactivity of these 4 -arm PEG-SDF1 $\alpha$ were tested (Figure 3(b)). The results showed that both 10MA-PEG-SDF $1 \alpha$ and 40MA-PEG-SDF $1 \alpha$ had dose dependency between 1 and $100 \mathrm{ng} / \mathrm{mL}$. In addition, 10MA-PEG-SDF $1 \alpha$ had significantly higher chemotactic bioactivity than 40MA-PEG-SDF1 $\alpha$. The reduced activity of 40MA-PEG as compared to 10MA-PEG could be due to greater spacing between cysSDF1 $\alpha$ on 40MA-PEG or greater steric hindrance from the 40MA-PEG backbone. Additionally, not only $10 \mathrm{ng} / \mathrm{mL}$ of 10MA-PEG displayed similar potency to $100 \mathrm{ng} / \mathrm{mL}$ of cSDF $1 \alpha$ and cysSDF $1 \alpha$, but also $100 \mathrm{ng} / \mathrm{mL}$ of 10MA-PEG successfully increase potency than $10 \mathrm{ng} / \mathrm{mL}$ of 10MA-PEG, suggesting 10MA-PEG has potential to avoid passive dimerization. Therefore, 10MA-PEG could be potentially used to maintain SDF1 $\alpha$ activity for delivery at high concentration. This mainly because the MA backbone structure linked to the back side of SDF1 $\alpha$ where SDF1 $\alpha$ used to dimerized to each other.

\subsection{Chemotactic Activity of SDF1 $\alpha$ Conjugated to HA}

Compared to MA-PEG, HA has far more potential conjugation sites and is bigger in size. The conjugation scheme is shown in Figure 4. Interestingly, HAconjugated SDF $1 \alpha$ had very low chemotactic bioactivity (Figure 5(a)). However, after we digested HAs with hyaluronidase for 1 hour or overnight, HA-SDF1 $\alpha$ fragments regained chemotactic activity (Figure 5(b)). These results suggest that HA might sterically hinder SDF1 $\alpha$ binding to its receptors on the cell surface. Presumably, once HA was fragmented, the conjugated proteins were dispersed and exposed so that the bioactivity was recovered. Therefore, HA could be used as a carrier of SDF1 $\alpha$ and the release of SDF1 $\alpha$ could be modulated by hyaluronidase secreted by cells in injured tissues, since an injured site contains hyaluronidases that can efficiently release SDF1 $\alpha$ from HA. This delivery approach enables local delivery and may reduce the risks associated with systemic administration of SDF1 $\alpha$. 
(a)

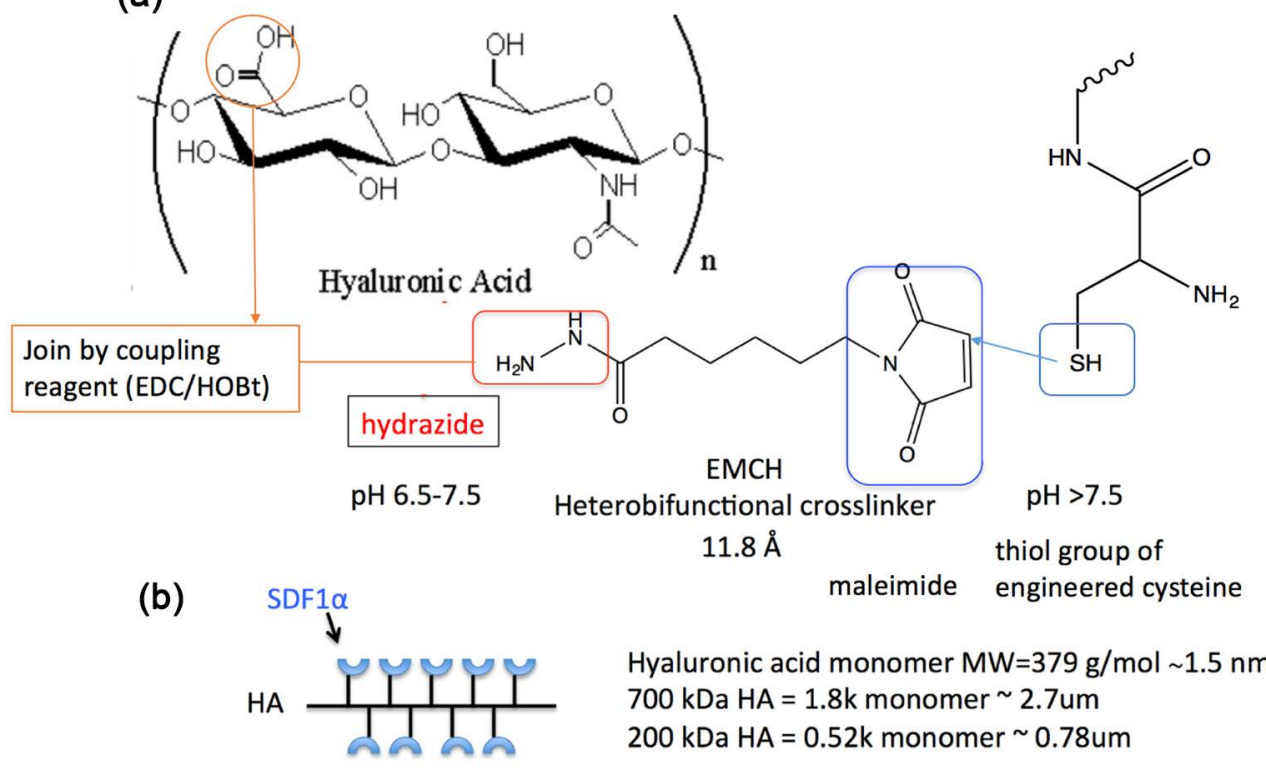

Linear-shape SDF cluster

Figure 4. The structure of HA. (a) EMCH is the linker between HA and cysSDF1 $\alpha$. Hydradize and carbonyl group of carboxylic acid are linked by EDC/HOBt while maleimide and thiol group of cysSDF1 $\alpha$ are linked by Michael addition. The reaction order is the joining of HA with EMCH first, and then linking the product to thiol group by Michael addition reaction. Reverse order causes intra cyclic reaction. To avoid side products, HA-EMCH linking needs to avoid acetate buffer in which acetate links to EMCH instead; (b) The topology and size of HA.

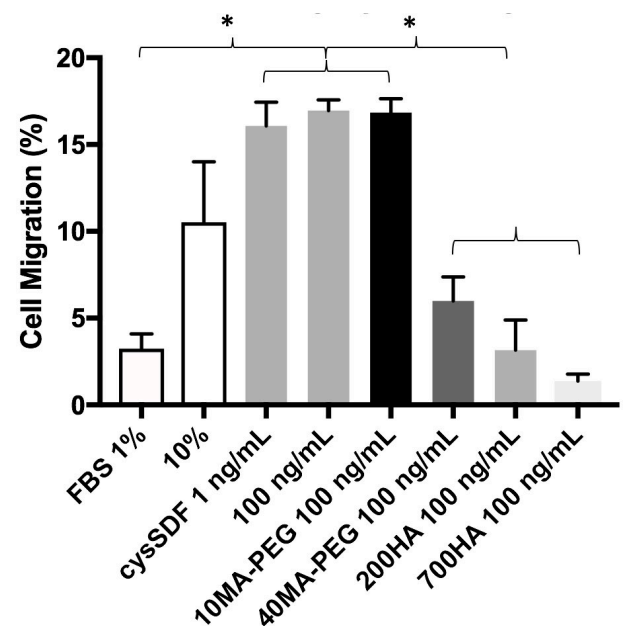

(a)

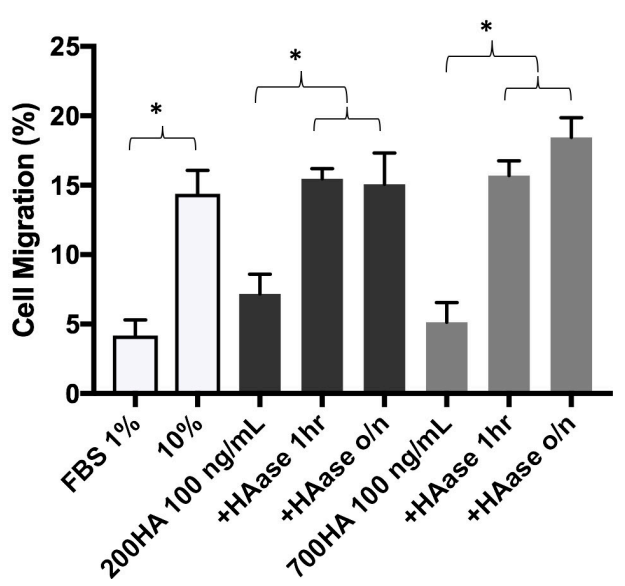

(b)

Figure 5. Chemotactic bioactivity of (a) 10MA-PEG, 40MA-PEG, $200 \mathrm{HA}$ and $700 \mathrm{HA}$ and (b) 700 HA after hyaluronidase digestion. Note: ${ }^{\star}$ indicates a pair has a statistically significant difference (p-value <0.05).

\section{Conclusions}

Since non-specific ligation of SDF1 $\alpha$ reduced the bioactivity, ligation of SDF1 $\alpha$ with site-specific bonding is necessary. Ligating SDF1 $\alpha$ with MA-PEG and HA 
respectively, we found that: 1) The smaller MA-PEG backbone performed better than the larger sized MA-PEG backbone. This may be explained by way of the longer arms of higher MW PEG keeping SDF1 $\alpha$ too far apart; 2) By ligating to the MA-PEG backbone, SDF1 $\alpha$ can increase potency at higher concentration, that is, the MA-PEG backbone can avoid SDF1 $\alpha$ passive dimerization; 3) While HA ligation greatly reduced SDF $1 \alpha$ bioactivity, it can be used as a strategy to load SDF1 $\alpha$ in HA for sustained release by hyaluronidase.

On balance, even though we have found useful information about carrier backbone selection, this work has suffered from a low yield of cysSDF1 $\alpha$ protein synthesis. We tried three different refolding buffer protocols for cysteine protein, but cysSDF1 $\alpha$ protein still showed high aggregation in refolding. Computational biology calculations and use of a different mutation site may possibly increase the stability of cysSDF $1 \alpha$ and by extension increase the protein yield. Once the protein yield is increased, our results could have more practical usage and they could also improve detection methods for 10 MA-PEG.

\section{Acknowledgements}

This work was supported by a grant from the National Institute of Health (HL121450, to S.L.). We thank Professor Gerard Marriott for technical support and valuable discussions, various members of the Department of Bioengineering and the Department of Chemistry at UC Berkeley, and Mary West at the Berkeley stem cell facility. In addition, the first author thanks for Joe Kileel for reading a draft of this work.

\section{References}

[1] Veldkamp, C.T., Seibert, C., Peterson, F.C., De la Cruz, N.B., Haugner 3rd, J.C., Basnet, H., Sakmar, T.P. and Volkman, B.F. (2008) Structural Basis of CXCR4 Sulfotyrosine Recognition by the Chemokine SDF-1/CXCL12. Science Signaling, 1, ra4. https://doi.org/10.1126/scisignal.1160755

[2] Lee, K.W., Johnson, N.R., Gao, J. and Wang, Y. (2013) Human Progenitor Cell Recruitment via SDF-1alpha Coacervate-Laden PGS Vascular Grafts. Biomaterials, 34, 9877-9885. https://doi.org/10.1016/j.biomaterials.2013.08.082

[3] Murphy, J.W., Cho, Y., Sachpatzidis, A., Fan, C., Hodsdon, M.E. and Lolis, E. (2007) Structural and Functional Basis of CXCL12 (Stromal Cell-Derived Factor-1 Alpha) Binding to Heparin. Journal of Biological Chemistry, 282, 10018-10027. https://doi.org/10.1074/jbc.M608796200

[4] Ferrari, R., Beltrami, C.A. and Tavazzi, L. (2010) Concerns and Hopes for Stem Cell Therapy in Cardiology: Focus on Endothelial Progenitor Cells. Cardiovascular \& Haematological Disorders-Drug Targets, 10, 216-223. https://doi.org/10.2174/1871529X11006030216

[5] Sumpio, B.E., Riley, J.T. and Dardik, A. (2002) Cells in Focus: Endothelial Cell. International Journal of Biochemistry \& Cell Biology, 34, 1508-1512. https://doi.org/10.1016/S1357-2725(02)00075-4

[6] Anderson, T.L., Gorstein, F. and Osteen, K.G. (1990) Stromal-Epithelial Cell Communication, Growth Factors, and Tissue Regulation. Laboratory Investigation, 62 , 519-521. 
[7] Bartczak, A., McGilvray, I. and Keating, A. (2017) Mesenchymal Stromal Cell Therapy to Promote Cardiac Tissue Regeneration and Repair. Current Opinion in Organ Transplantation, 22, 86-96.

[8] Luo, Q., Zhang, B., Kuang, D. and Song, G. (2016) Role of Stromal-Derived Factor-1 in Mesenchymal Stem Cell Paracrine-Mediated Tissue Repair. Current Stem Cell Research \& Therapy, 11, 585-592. https://doi.org/10.2174/1574888X11666160614102629

[9] Nakagami, H., Morishita, R., Maeda, K., Kikuchi, Y., Ogihara, T. and Kaneda, Y. (2006) Adipose Tissue-Derived Stromal Cells as a Novel Option for Regenerative Cell Therapy. Journal of Atherosclerosis and Thrombosis, 13, 77-81. https://doi.org/10.5551/jat.13.77

[10] Petrella, F., Rizzo, S., Borri, A., Casiraghi, M. and Spaggiari, L. (2015) Current Perspectives in Mesenchymal Stromal Cell Therapies for Airway Tissue Defects. Stem Cells International, 2015, Article ID: 746392. https://doi.org/10.1155/2015/746392

[11] Schaffler, A. and Buchler, C. (2007) Concise Review: Adipose Tissue-Derived Stromal Cells-Basic and Clinical Implications for Novel Cell-Based Therapies. Stem Cells, 25, 818-827. https://doi.org/10.1634/stemcells.2006-0589

[12] Zhao, W., Jin, K., Li, J., Qiu, X. and Li, S. (2017) Delivery of Stromal Cell-Derived Factor 1alpha for In Situ Tissue Regeneration. Journal of Biological Engineering, 11, 22. https://doi.org/10.1186/s13036-017-0058-3

[13] Guerin, E., Sheridan, C., Assheton, D., Kent, D., Wong, D., Grant, M. and Hiscott, P. (2008) SDF1-Alpha Is Associated with VEGFR-2 in Human Choroidal Neovascularisation. Microvascular Research, 75, 302-307. https://doi.org/10.1016/j.mvr.2007.12.001

[14] Kokovay, E., Goderie, S., Wang, Y., Lotz, S., Lin, G., Sun, Y., Roysam, B., Shen, Q. and Temple, S. (2010) Adult SVZ Lineage Cells Home to and Leave the Vascular Niche via Differential Responses to SDF1/CXCR4 Signaling. Cell Stem Cell, 7, 163-173. https://doi.org/10.1016/j.stem.2010.05.019

[15] Bobadilla, M., Sainz, N., Abizanda, G., Orbe, J., Rodriguez, J.A., Paramo, J.A., Prosper, F. and Perez-Ruiz, A. (2014) The CXCR4/SDF1 Axis Improves Muscle Regeneration through MMP-10 Activity. Stem Cells and Development, 23, 1417-1427. https://doi.org/10.1089/scd.2013.0491

[16] DeLeve, L.D., Wang, X. and Wang, L. (2016) VEGF-sdf1 Recruitment of CXCR7+ Bone Marrow Progenitors of Liver Sinusoidal Endothelial Cells Promotes Rat Liver Regeneration. American Journal of Physiology-Gastrointestinal and Liver Physiology, 310, G739-G746. https://doi.org/10.1152/ajpgi.00056.2016

[17] Merino, J.J. and Oset-Gasque, M.J. (2013) The CXCR7 Activation by SDF1 Induces Neural Progenitor Migration (NPC): A Dual Effect on CXCR4/CXCR7 Axis within the Vascular Niche of Ischemic Rats. International Journal of Stroke, 8, E56. https://doi.org/10.1111/ijs.12174

[18] Koch, K.C., Schaefer, W.M., Liehn, E.A., Rammos, C., Mueller, D., Schroeder, J., Dimassi, T., Stopinski, T. and Weber, C. (2006) Effect of Catheter-Based Transendocardial Delivery of Stromal Cell-Derived Factor 1alpha on Left Ventricular Function and Perfusion in a Porcine Model of Myocardial Infarction. Basic Research in Cardiology, 101, 69-77. https://doi.org/10.1007/s00395-005-0570-3

[19] Yu, J., Wang, A., Tang, Z., Henry, J., Li-Ping Lee, B., Zhu, Y., Yuan, F., Huang, F. and Li, S. (2012) The Effect of Stromal Cell-Derived Factor-1alpha/Heparin Coating of Biodegradable Vascular Grafts on the Recruitment of Both Endothelial and 
Smooth Muscle Progenitor Cells for Accelerated Regeneration. Biomaterials, 33, 8062-8074. https://doi.org/10.1016/j.biomaterials.2012.07.042

[20] Baumann, L., Prokoph, S., Gabriel, C., Freudenberg, U., Werner, C. and Beck-Sickinger, A.G. (2012) A Novel, Biased-Like SDF-1 Derivative Acts Synergistically with Star PEG-Based Heparin Hydrogels and Improves EEPC Migration in Vitro. Journal of Controlled Release, 162, 68-75. https://doi.org/10.1016/j.jconrel.2012.04.049

[21] Cuchiara, M.L., Horter, K.L., Banda, O.A. and West, J.L. (2013) Covalent Immobilization of Stem Cell Factor and Stromal Derived Factor 1alpha for in Vitro Culture of Hematopoietic Progenitor Cells. Acta Biomaterialia, 9, 9258-9269. https://doi.org/10.1016/j.actbio.2013.08.012

[22] Fernandez-Muinos, T., Recha-Sancho, L., Lopez-Chicon, P., Castells-Sala, C., Mata, A. and Semino, C.E. (2015) Bimolecular Based Heparin and Self-Assembling Hydrogel for Tissue Engineering Applications. Acta Biomaterialia, 16, 35-48. https://doi.org/10.1016/j.actbio.2015.01.008

[23] Krieger, J.R., Ogle, M.E., McFaline-Figueroa, J., Segar, C.E., Temenoff, J.S. and Botchwey, E.A. (2016) Spatially Localized Recruitment of Anti-Inflammatory Monocytes by SDF-1alpha-Releasing Hydrogels Enhances Microvascular Network Remodeling. Biomaterials, 77, 280-290. https://doi.org/10.1016/j.biomaterials.2015.10.045

[24] Prokoph, S., Chavakis, E., Levental, K.R., Zieris, A., Freudenberg, U., Dimmeler, S. and Werner, C. (2012) Sustained Delivery of SDF-1alpha from Heparin-Based Hydrogels to Attract Circulating Pro-Angiogenic Cells. Biomaterials, 33, 4792-4800. https://doi.org/10.1016/j.biomaterials.2012.03.039

[25] He, M.Q., He, M.Q., Wang, J.F., Zhu, B.L., Sun, N., Zhou, X.H. and Yao, R.X. (2016) Vascular Endothelial Growth Factor and Cluster of Differentiation 34 for Assessment of Perioperative Bleeding Risk in Gastric Cancer Patients. Chinese Medical Journal, 129, 1950-1954. https://doi.org/10.4103/0366-6999.187842

[26] Khan, I.M., Palmer, E.A. and Archer, C.W. (2010) Fibroblast Growth Factor-2 Induced Chondrocyte Cluster Formation in Experimentally Wounded Articular Cartilage Is Blocked by Soluble Jagged-1. Osteoarthritis Cartilage, 18, 208-219. https://doi.org/10.1016/j.joca.2009.08.011

[27] Altincicek, B., Shibamiya, A., Trusheim, H., Tzima, E., Niepmann, M., Linder, D., Preissner, K.T. and Kanse, S.M. (2006) A Positively Charged Cluster in the Epidermal Growth Factor-Like Domain of Factor VII-Activating Protease (FSAP) Is Essential for Polyanion Binding. Biochemical Journal, 394, 687-692. https://doi.org/10.1042/BJ20051563

[28] De Rosa, L., Cortajarena, A.L., Romanelli, A., Regan, L. and D’Andrea, L.D. (2012) Site-Specific Protein Double Labeling by Expressed Protein Ligation: Applications to Repeat Proteins. Organic \& Biomolecular Chemistry, 10, 273-280. https://doi.org/10.1039/C1OB06397A

[29] Ghosh, I., Considine, N., Maunus, E., Sun, L., Zhang, A., Buswell, J., Evans, T.C. and $\mathrm{Xu}$, M.Q. (2011) Site-Specific Protein Labeling by Intein-Mediated Protein Ligation. Methods in Molecular Biology, 705, 87-107. https://doi.org/10.1007/978-1-61737-967-3_6

[30] Helms, B., van Baal, I., Merkx, M. and Meijer, E.W. (2007) Site-Specific Protein and Peptide Immobilization on a Biosensor Surface by Pulsed Native Chemical Ligation. Chembiochem, 8, 1790-1794. https://doi.org/10.1002/cbic.200700355

[31] Kalia, J., Abbott, N.L. and Raines, R.T. (2007) General Method for Site-Specific Pro- 
tein Immobilization by Staudinger Ligation. Bioconjugate Chemistry, 18, 1064-1069. https://doi.org/10.1021/bc0603034

[32] Lovrinovic, M., Fruk, L., Schroder, H. and Niemeyer, C.M. (2007) Site-Specific Labeling of DNA-Protein Conjugates by Means of Expressed Protein Ligation. Chemical Communications, No. 4, 353-355. https://doi.org/10.1039/B614978B

[33] Soellner, M.B., Dickson, K.A., Nilsson, B.L. and Raines, R.T. (2003) Site-Specific Protein Immobilization by Staudinger Ligation. Journal of the American Chemical Society, 125, 11790-11791. https://doi.org/10.1021/ja036712h

[34] Vernet, E., Sauer, J., Andersen, A., Jensen, K.J. and Voldborg, B. (2011) Predictive Mutagenesis of Ligation-Independent Cloning (LIC) Vectors for Protein Expression and Site-Specific Chemical Conjugation. Analytical Biochemistry, 414, 312-314. https://doi.org/10.1016/j.ab.2011.03.015

[35] Warden-Rothman, R., Caturegli, I., Popik, V. and Tsourkas, A. (2013) Sortase-Tag Expressed Protein Ligation: Combining Protein Purification and Site-Specific Bioconjugation into a Single Step. Analytical Chemistry, 85, 11090-11097.

https://doi.org/10.1021/ac402871k 